POLITYKA ENERGETYCZNA - ENERGY POLICY JOURNAL

$2019 \uparrow$ Volume $22 \uparrow$ Issue $2 \uparrow 89-106$

DOI: $10.33223 / \mathrm{epj} / 108706$

Jan KuCHMACZ ${ }^{1}$, Artur BIENIEK ${ }^{2}$, Lukasz MiKA $^{3}$

\title{
The use of adsorption chillers for waste heat recovery
}

ABSTRACT: The purpose of this article was to discuss the use of adsorption chillers for waste heat recovery. The introduction discusses the need to undertake broader measures for the effective management of waste heat in the industry and discusses the benefits and technical problems related to heat recovery in industrial plants. In addition, heat sources for adsorption chillers and their application examples were described. The principle of operation of adsorption chillers is explained in the next chapter. Heat sources for adsorption chillers are indicated and their application examples are described. The above considerations have allowed the benefits and technical obstacles related to the use of adsorption chillers to be highlighted. The currently used adsorbents and adsorbates are discussed later in the article. The main part of the paper discusses the use of adsorption chillers for waste heat management in the glassworks. The calculations assumed the natural gas demand of 20.1 million $\mathrm{m}^{3}$ per year and the electricity demand of 20,000 MWh/year. As a result of conducted calculations, a $231 \mathrm{~kW}$ adsorption chiller, ensuring the annual cold production of 2,021 MWh, was selected. The economic analysis of the proposed solution has shown that the investment in the adsorption chiller supplied with waste heat from the heat recovery system will bring significant economic benefits

$\triangle$ Corresponding Author: Jan Kuchmacz; e-mail: jan.kuchmacz@pk.edu.pl

${ }^{1}$ Cracow University of Technology, Faculty of Mechanical Engineering, Institute of Thermal and Process Engineering, Division of Refrigeration and Air Conditioning, Krakow, Poland; ORCID iD: 0000-0002-7100-7264; e-mail: jan.kuchmacz@pk.edu.pl

2 Department of Fluid and Flow Machines, AGH University of Science and Technology, Krakow, Poland; ORCID iD: 0000-0001-6965-4369; e-mail: bieniek@agh.edu.pl

3 Department of Fluid and Flow Machines, AGH University of Science and Technology, Krakow, Poland, ORCID iD: 0000-0002-0750-7694; e-mail: lmika@agh.edu.pl

2019. The Author(s). This is an open-access article distributed under the terms of the Creative Commons Attribution-ShareAlike International License (CC BY-SA 4.0, http://creativecommons.org/licenses/by-sa/4.0/), which permits use, distribution, and reproduction in any medium, provided that the Article is properly cited. 
after 10 years from its implementation, even with total investment costs of PLN 1,900,000. However, it was noted that in order to obtain satisfactory economic results the production must meet the demand while the cost of building a heat recovery system shall not exceed PLN 1 million.

KEYWORDS: waste heat, heat recovery, energy efficiency, adsorption refrigerators

\section{Introduction}

Commission communication on a policy framework for climate and energy from 2020 to $2030-\operatorname{COM}(2014) 0015$ obliges the EU member states to undertake actions aimed at increasing the energy efficiency (Commission communication... 2014). The implementation of this obligation by industrial plants means results in the need for using energy conversion technologies characterized by higher efficiency and to broaden the scope of waste heat management. The need for waste heat management arises from both ecological and economic points of view. It should be noted that low energy efficiency, understood as the efficiency of converting primary energy into usable energy, is related to a high unit cost of useful energy (Kuchmacz and Mika 2018).

Industrial production generates significant amounts of waste heat as a result of the operation of such commonly used equipment as: steel furnaces, glass furnaces, boilers, internal combustion engines, etc. A significant part of this heat can be used effectively, because the technologies that allow the conversion of waste heat into usable energy are already available in the market. They include, among others, ORC power plants, mobile heat storage units, or adsorption devices. The last of the mentioned energy technologies is increasingly used in the industry due to the need to produce cold for technological purposes and to ensure comfortable working conditions.

\section{The idea of heat recovery from industrial processes}

All industrial processes require the supply of energy in the form of heat, mechanical energy, or electricity. Part of this energy is used in industrial process, while the rest of it is dissipated in the form of waste heat. It is estimated that industrial plants in the European Union, such as refineries, steelworks, glassworks, cement plants, paper mills, etc., covered by the European Union Emission Trading System (EU ETS), generate 36-71 PJ of waste heat per year (Hammond and Norman 2014). The effective management of this heat could provide numerous ecological and economic benefits for EU countries and contribute to the increase of competitiveness of European enterprises on global markets. However, waste heat recovery and its effective use are hindered by numerous technological and economic obstacles. 
Waste heat generated during industrial production can be used in various ways. Thanks to the development of ORC technology (Organic Rankine Cycle), it is possible to convert waste heat into electricity. Modern micro ORC plants can be supplied with a working medium at a temperature lower than $100^{\circ} \mathrm{C}$, which enables the use of low temperature heat (Weisser and Skotnicki 2016). Another method of waste heat management is its use to heat industrial premises and supply them with hot water. This waste heat management method is usually technically less complicated, as there is no need for energy conversion, although the demand of an industrial plant for heating and hot water is usually low and only part of the waste energy can be used efficiently. Waste heat can also be recovered thanks to the use of devices such as heat exchangers or combustion air heaters (Kuchmacz and Mika 2018). In addition to the above-mentioned exemplary applications, waste heat can be used to produce cold using sorption chillers. The use of any of the above solutions brings ecological benefits since the waste heat partially or completely replaces the heat produced as a result of the combustion of fossil fuels for heating, domestic hot water preparation, or electricity production. In light of the above, the management of waste heat contributes to the reduction of greenhouse gas emissions and harmful substances. Heat recovery can also bring economic benefits for an industrial plant, which will result, depending on the chosen management method, from own production of electricity or the reduction of fuel consumption.

The use of waste heat from industrial processes requires overcoming numerous technical and economic barriers. Technical problems include finding suitable technology for heat recovery, which in the case of industrial processes is often released from many different spatial locations. The heat recovery system must fulfill two basic conditions: enable the recovery of as much waste heat as possible and cannot hinder the industrial process. It should be noted that an increase or decrease in temperature or pressure during the industrial process, as a result of using heat recovery installations, can hinder its course and consequently reduce the quality of production. Another problem is the fact that waste heat can be produced periodically, which results from the specificity of the industrial process and plant operation. In this case, there is a need to meet the energy demand of the plant from other sources than waste heat. Technical problems related to the management of waste heat also result from the fact that the heat transfer is related to the convection of gases generated in a given industrial process, which may adversely affect the heat recovery system. For example, if these gases have corrosive properties, then special materials for the construction of heat exchangers are necessary. Hazards can also occur when the flammable refrigerant leaks from the heat recovery system. The above mentioned technical problems necessitate the use of devices dedicated to specific conditions prevailing in a given industrial plant, which increases the investment costs of heat recovery systems. Economic viability is always an issue, especially when taking the fact that installations used for heat recovery would be used almost exclusively in enterprises that is entities focused on generating economic benefits into account. 


\section{The principle of operation of adsorption chillers}

Adsorption chillers are comprised of several main elements: an adsorbent bed (or several beds), an evaporator, a condenser, a throttle valve and shut-off valves. When describing the principle of operation of adsorption chillers, it was assumed that the working medium (adsorbate) is water. The operation cycle of the refrigeration equipment (Fig. 1) consists of the following steps: isosteric (with a constant mass of adsorbed steam) heating of the bed (A-B), isobaric desorption (bed regeneration) and condensation of water vapor in the condenser (B-C), isosteric cooling of the bed (C-D), and evaporation of water in the evaporator and isobaric adsorption of water vapor in the bed (D-A). As a result of $Q_{o}$ heat supply, the pressure and temperature increase in the bed heating stage. This stage is continued until the pressure in the bed reaches the condensation pressure $p_{d}$. Then, as a result of supplying the $Q_{d}$ heat to the system, desorption in the bed and condensation in the condenser take place. Water vapor is released from the adsorbent and is condensed in the condenser; as a result, $Q_{S}$ heat is supplied to the upper source. This stage ends with regeneration of the adsorbent bed. Then, the adsorbent is cooled, which is accompanied by a heat release $Q_{c}$, resulting in a drop in temperature and pressure. This process occurs until the pressure in the bed is equal to the evaporation pressure $p_{a}$. Then, as a result of heat absorption $Q_{p}$ from the bottom source, the evaporation of the adsorbate in the evaporator begins. The water vapor (adsorbate) formed in this way is adsorbed in the adsorbent bed, which is accompanied by a $Q_{a}$ heat release. The effect of this process is saturation of the adsorbent bed with water vapor.

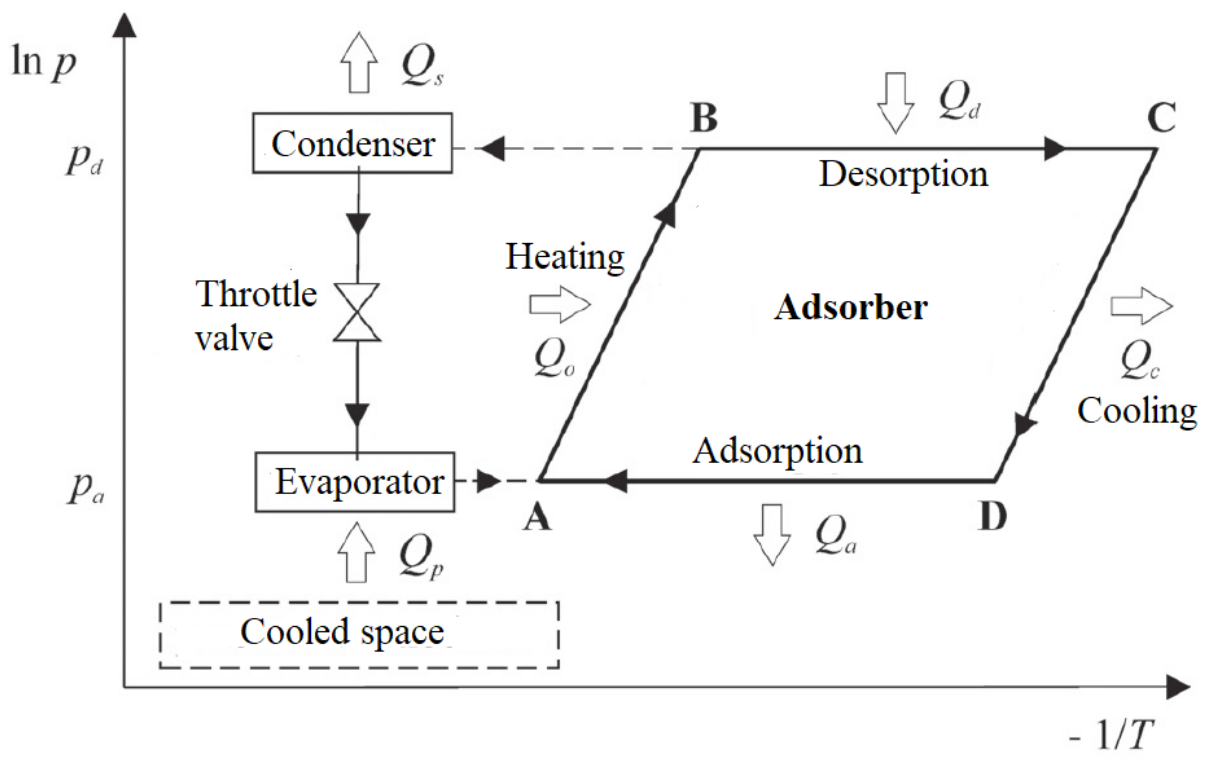

Fig. 1. Adsorption refrigeration cycle (Gwadera and Kupiec 2011)

Rys. 1. Cykl przemian zachodzących w chłodziarce adsorpcyjnej 
The efficiency of the adsorption chiller is described by the coefficient of performance (COP):

$$
C O P=\frac{Q_{p}}{Q_{o}+Q_{d}}
$$

where:

$Q_{p}-$ cooling capacity,

$Q_{o}-$ the heat supplied to the adsorbent bed in the heating stage,

$Q_{d}-$ the heat supplied to the adsorbent bed during the desorption stage (Gwadera and Kupiec 2014).

\section{Heat sources for adsorption chillers}

Adsorption refrigeration systems are characterized by a low coefficient of performance COP compared to their compressor and absorption counterparts (Gwadera and Kupiec 2014; Ambarita and Kawai 2016; Li et al. 2016; Hamrahi et al. 2018; Najeh et al. 2016). In connection with the above, it is most advantageous to supply these systems with waste heat, solar energy, or geothermal energy.

The greatest demand for cooling power is usually found in countries with a hot climate, e.g. in the geographical regions of the highest exposure to sunlight. For this reason, in the literature on the subject (Gwadera and Kupiec 2014; Ambarita and Kawai 2016; Li et al. 2016; Hamrahi et al. 2018; Bagdujew and Czałajew 2008; Rudenko 2008; Rudenko and Szypulina 2011) special attention is paid to solar-powered adsorption chillers. The solar-powered adsorption refrigeration system (Fig. 2) contains the following elements: the adsorbent bed (1) in the solar collector (2), the air-cooled condenser (3), and the evaporator (4) in the cooling chamber (5). During the day, the solar radiation heats the adsorbent to a temperature of $100-110^{\circ} \mathrm{C}$, as a result of which the adsorbate is desorbed (Bagdujew and Czałajew 2008). The adsorbate vapors are transferred to the condenser where their condensation takes place. As a result of this process, the refrigerant in the liquid phase flows from the condenser to the evaporator. The desorption process ends with the full regeneration of the adsorbent if the sun exposure on a given day allows for the desorption of the entire adsorbate. After sunset, the temperature of the adsorbent decreases, which results in the pressure drop in the system to the evaporating pressure. As a result of this process, the medium starts boiling in the evaporator and its vapors are adsorbed by the bed. The cooling process continues until all the refrigerant evaporates from the evaporator. The result of this process is the formation of ice in the evaporator tray, which allows low temperature in the refrigeration chamber during the next day to be maintained, when the desorption and condensation stages take place (Rudenko 2008). 


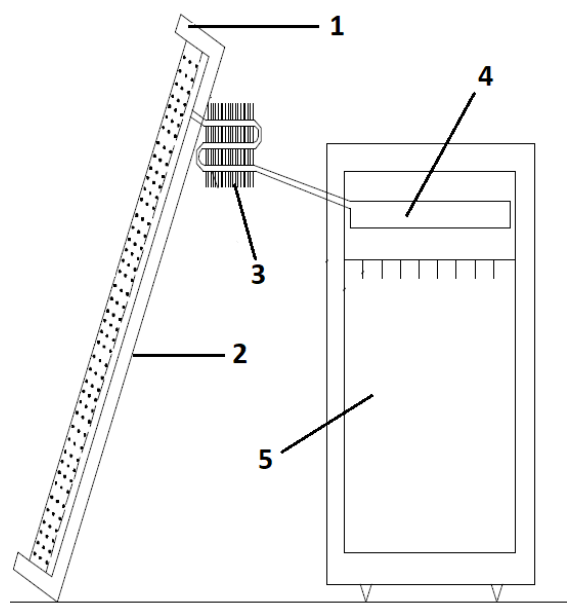

Fig. 2. Solar-powered adsorption chiller

1 - adsorption bed, 2 - solar collector, 3 - air-cooled condenser, 4 - evaporator, 5 - refrigerator compartment

(Bagdujew and Czałajew 2008)

Rys. 2. Adsorpcyjny układ chłodniczy zasilany energią słoneczną

1 -złoże adsorbentu, 2 - kolektor słoneczny, 3 - skraplacz chłodzony powietrzem, 4 - parownik,

5 - komora chłodnicza

The idea of supplying adsorption cooling systems with hot water from geothermal sources has so far not been widely used. This is evidenced by limited data on the subject in the literature (Kuczyńska and Szaflik 2010; Al-Mousawi et al. 2016). The problem of the lack of interest in geothermal waters as a source of heat for adsorption chillers stems from the fact that in order to operate efficiently these devices require heat sources with high temperatures, often exceeding $100^{\circ} \mathrm{C}$ (Kuczyńska and Szaflik 2010). Meanwhile, based on the data of the Polish Geological Institute, it can be concluded that geothermal waters of this temperature occur in Poland at a depth of at least $2000 \mathrm{~m}$. This, combined with a low COP of adsorption cooling systems, makes such investments unlikely (Thermalwaters 2014). A solution to this problem is to look for new materials for both adsorbents and adsorbates, which would allow a more effective operation of adsorption chillers at lower temperatures of the heating medium.

Adsorption refrigeration systems can also be used in industrial processes where significant amounts of waste heat are generated (Gwadera and Kupiec 2011). In the literature on the subject one can find descriptions of attempts to use these devices for waste heat management in the chemical industry, metallurgy, glassworks, power plants, and on ships (Grzebielec 2005; Jiangzhou et al. 2003; Wang et al. 2004). This issue is discussed in detail later in the article. 


\section{The use of adsorption chillers}

So far, one can indicate three basic applications of adsorption chillers: air-conditioning $\left(8-15^{\circ} \mathrm{C}\right)$, refrigeration to store food and medicines $\left(0-8^{\circ} \mathrm{C}\right)$, and freezing for food preservation or ice production $\left(<0^{\circ} \mathrm{C}\right)$ (Gwadera and Kupiec 2011).

As mentioned earlier, the adsorption cooling devices are used primarily in countries with a hot climate, where it is possible to use large amounts of solar energy as a source of heat. The prospect of using solar radiation energy for the production of cold and desalination of drinking water is particularly attractive for low-developed countries, where access to electricity is limited. In this case, the adsorption chillers successfully replace the compressor and absorption chillers (Fan et al. 2007).

In recent years, numerous attempts have been made to construct adsorption chillers with a cooling power below $20 \mathrm{~kW}$, designed to provide comfort conditions in summer in small enterprises and single-family homes. Some of these attempts resulted in the commercialization of prototypes, as exemplified by Fahrenheit products. In the near future, the adsorption chiller developed by Dutch scientists from the ECN (Energy Research Center of the Netherlands) with a cooling capacity of $2.5 \mathrm{~kW}$ and a coefficient of performance of 0.5 (Bakker et al. 2013) will be available on the market. The device is to be supplied with heat produced by the CHP (Combined Heat and Powerunit) using natural gas as fuel (Fig. 3). In the period of high external temperatures, when the heat produced by the CHP unit is not fully used, the adsorption cooler will enable its efficient management.

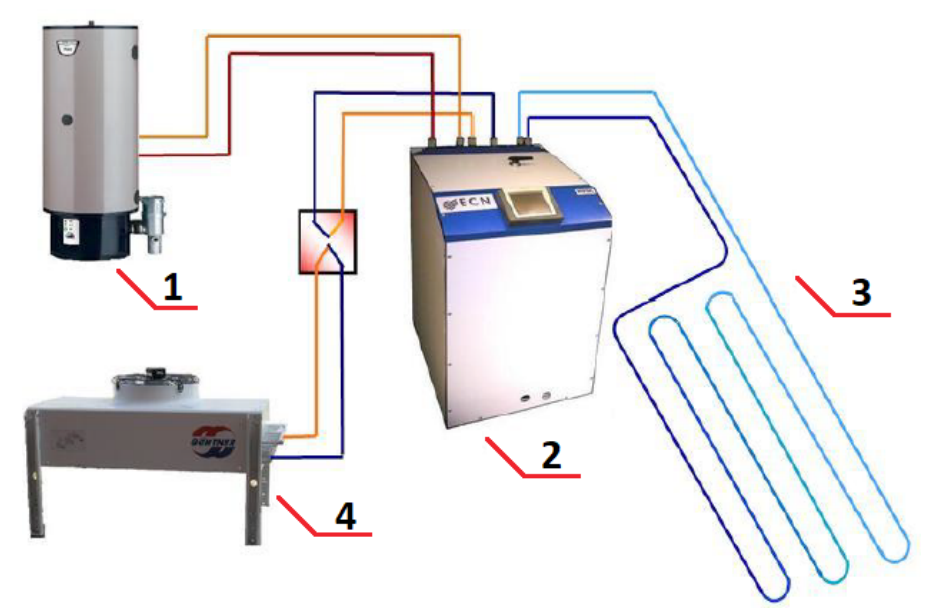

Fig. 3. The system proposed by ECN

1 - CHP unit, 2 - adsorption chiller, 3 - cooling installation, 4 - dry cooler (Bakker et al. 2013)

Rys. 3. Instalacja zaproponowana przez ECN

1 - jednostka CHP, 2 - chłodziarka adsorpcyjna, 3 - instalacja chłodnicza, 4 - sucha chłodnica 
Adsorption chillers powered by waste heat can be used not only in heavy industry, but also in places where the amount of waste heat generated is much lower. In the literature on the subject one can find examples of the use of these devices for air conditioning of locomotive driver-cabins (using heat energy from the exhaust gases produced by engines) or for fish preservation on fishing boats (using the heat energy from diesel engine exhaust) (Jiangzhou et al. 2003; Wang et al. 2004). An interesting example of waste heat management using adsorption chillers is the solution proposed by the Ukrainian company Caxapa, which involves air conditioning of server rooms using the heat generated during the operation of the servers (Adsorption machines... 2016).

\section{Advantages and technical barriers related to the use of adsorption chillers}

The increase in interest in adsorption chillers results primarily from the fact that their negative impact on the environment is negligible. However, numerous technical problems associated with their application and low values of the coefficient of performance COP are the reason why in many cases adsorption chillers are not competitive in comparison to compressor and absorption devices.

The basic advantage associated with the operation of adsorption chillers is their low demand for electricity. According to the manufacturers data, the EER coefficient (the ratio of the cooling capacity to the power input) of these refrigeration devices reaches values close to 30 (Adsorption machines... 2016). Electricity is consumed only for the purpose of controlling the refrigerator, while the energy is obtained from heat. The use of adsorption chillers in place of compressor or absorption chillers can therefore decrease the load on the power grid during summer and afternoon hours, i.e. when the greatest demand for cooling takes place. The use of solar energy, geothermal energy, and waste energy as a source of heat is another environmental advantage of this device, making it independent of electricity supplies. The use of adsorptive chillers is also supported by the fact that the working mediums (e.g. water) used in them are environmentally friendly and do not damage the ozone layer (Gwadera and Kupiec 2011). Manufacturers of adsorption chillers also pay attention to their quiet and maintenance-free operation, simple construction, the fact that they contain no moving parts, and their reliability and longevity (Adsorption cooling... 2013). In addition, adsorption chillers are characterized by simple control, lack of vibration and corrosion problems (Gwadera and Kupiec 2011).

The greatest obstacle for the popularization of adsorption chillers is their low coefficient of performance $\mathrm{COP}$, which, according to literature data, usually does not exceed 0.7 (Gwadera and Kupiec 2011; Ambarita and Kawai 2016; Li et al. 2016; Najeh et al. 2016; Adsorption cooling... 2016). This means that the production of $1 \mathrm{~kW}$ of cold requires at least $1.43 \mathrm{~kW}$ of heat. In light of 
the above, the use of adsorption chiller can only be economically viable when it is supplied with renewable energy or waste heat. Otherwise, taking the obtained results and the current prices of electricity and district heating in Poland into account, it can be stated that the competitiveness of adsorption chillers to their compressor counterparts would require the coefficient of performance of at least 1.52 (Grzebielec et al. 2015). Another challenge associated with the operation of these refrigeration devices is the discontinuity of their operation, i.e. the periodicity of cold production, which was indicated in the fourth point when describing the operation of the solar-powered adsorption chiller. This problem is solved by using at least two adsorbent beds operating cyclically as adsorber/desorber in antiphase (Gwadera and Kupiec 2011; Bakker et al. 2013). This solution enables the continuous production of cooling power. Another disadvantage is the large size and mass of adsorptive coolers compared to compressor and absorption chillers. For example, the weight of ПТР (Prostranstwo Tocznych Rieszenij) adsorption chiller with a cooling capacity of $430 \mathrm{~kW}$ is almost $20 \mathrm{t}$ (Adsorption cooling... 2013). An important problem is the fact that the investment costs associated with the purchase of adsorption chillers are much higher than in the case of absorption and compressor chillers (Air conditioning... 2017). Naturally, the weight of the adsorption chillers and the fact that few manufacturers make them have a major impact on the high costs of these devices.

\section{The used adsorbents and adsorbates}

The selection of a suitable adsorbent - adsorbate system has a key impact on the performance of the adsorption chiller (Hamrahi et al. 2018; Najeh et al. 2016). A properly selected system should be characterized by a high adsorption capacity and its high variability depending on the temperature (Gwadera and Kupiec 2011).

Chemical compounds used as adsorbates include: ammonia $\left(\mathrm{NH}_{3}\right)$, methylamine $\left.\mathrm{CH}_{3} \mathrm{NH}_{2}\right)$, ethylamine $\left(\mathrm{C}_{2} \mathrm{H}_{5} \mathrm{NH}_{2}\right)$, dimethylamine $\left(\left(\mathrm{CH}_{3}\right)_{2} \mathrm{NH}\right)$, methanol $\left(\mathrm{CH}_{3} \mathrm{OH}\right)$, ethanol $\left(\mathrm{C}_{2} \mathrm{H}_{5} \mathrm{OH}\right)$, and water $\left(\mathrm{H}_{2} \mathrm{O}\right)$ (Rudenko and Szypulina 2011). The requirements for adsorbates include: low evaporation temperature, low saturation pressure at a normal operating temperature, high heat of evaporation, small particle size, chemical stability with respect to the adsorbent and other elements of the system, non-toxicity, non-flammability and the lack of corrosive activity (Gwadera and Kupiec 2011).

Activated carbon, silica gel, zeolites, calcium chloride and composite compounds are most commonly used as adsorbents (Rudenko and Szypulina 2011). The requirements for adsorbents include: the ability to adsorb as much adsorbate at low pressure as possible, the ability to desorb the largest possible amount of adsorbate under high pressure, and the durability of properties over time (Gwadera and Kupiec 2011).

The analysis of literature sources allows us to state that we are currently looking for an inexpensive as possible adsorbent-adsorbate system that would meet the above requirements, 
and allow for achieving a high COP after being used in the adsorption chiller. In connection with the above, numerous scientific studies are carried out on the following adsorbent-adsorbate systems: silica gel-water, zeolites-water, activated carbon-methanol, activated carbon-ethanol, activated carbon-ammonia, calcium chloride-ammonia, and composite compounds-ammonia (Ambarita and Kawai 2016). Many studies in recent years have been focused on silica gel-water and activated carbon-ammonia systems (Hamrahi et al. 2018).

Laboratory tests of silica-water adsorption chillers have shown a relatively high cooling capacity compared to chillers in which another adsorbent or adsorbate was used (Hamrahi et al. 2018; Najeh et al. 2016). Restuccia et al. (Restuccia et al. 2004) examined an adsorption cooler supplied with a temperature of $90-95^{\circ} \mathrm{C}$ and obtained a COP of 0.6. Boelman et al. (Boelman et al. 1995), supplying a temperature of only $50^{\circ} \mathrm{C}$, obtained a COP of 0.4. Researchers from $\mathrm{ECN}$ have developed a ready-to-market prototype of a $2.5 \mathrm{~kW}$ adsorption chiller powered by a medium at a temperature of $80^{\circ} \mathrm{C}$, with a COP of 0.5 (Bakker et al. 2013). The silica gel - water system enables the use of low-temperature heat, which results from the fact that the silica gel regeneration process can take place at relatively low temperatures (Najeh et al. 2016). Another advantage of this system is its environmental friendliness and a high heat of phase transformation of water.

A methanol-activated carbon adsorption chiller has a much lower coefficient of performance compared to a silica- gel-water chiller (Hamrahi et al. 2018). Pralon and Daguenet (Pralon and Daguent 2000) analyzed a solar-powered methanol-activated carbon adsorption chiller. The heat was generated by solar collectors covered with a transparent thermal insulation material. The obtained coefficient of performance (COP) was 0.13 . This COP value is much higher than the 0.032 value obtained by Song et al. (Song et al. 2015) at a desorption temperature of $94^{\circ} \mathrm{C}$. The evaluation of carbon-active methanol system is, however, of great importance due to the possibility of powering the adsorption chiller equipped with this system with low temperature heat and numerous advantages of methanol, including the high evaporation of heat, low freezing point, or no corrosive activity in relation to steel or copper components of the chiller (Pralon and Daguent 2000).

\section{The management of waste heat from industrial processes using adsorption chillers}

Adsorption chillers can be powered by waste heat from industrial processes. The glass industry is one of the industries that should be considered in the context of waste heat management due to high temperatures during the glass melting process. The chill generated by the adsorption chiller can be used in a glassworks, to improve the thermal conditions in the workplace, or in cooling equipment and industrial devices. 


\subsection{The estimated amounts of produced cold and the cooling capacity of the adsorption chiller installed in the glassworks}

Using a cooling system based on adsorption chiller in a glassworks, whose demand for natural gas is 20.1 million $\mathrm{m}^{3}$ per year while the demand for electricity is $20.000 \mathrm{MWh}$ /year was decided. It was assumed that the calorific value of Ls type nitrogen-rich natural gas (formerly GZ-35) is $24 \mathrm{MJ} / \mathrm{m}^{3}$. Another assumption was that $75 \%$ of the energy supplied to the glassworks, in the form of electricity and chemical energy of the fuel, will be converted into waste heat. After estimating the amount of waste heat it was assumed that $5 \%$ of this heat can be recovered. The above pessimistic assumption results from the fact that the largest part of the waste heat is discharged with exhaust gases. The results of the calculations are presented in Table 1.

TABLE 1. The estimation of the amount of recovered heat

TABELA 1. Oszacowanie odzyskanej ilości ciepła odpadowego

\begin{tabular}{|c|c|c|c|c|}
\hline $\begin{array}{c}\text { Demand for electricity } \\
{[\mathrm{MWh} / \text { year }]}\end{array}$ & $\begin{array}{c}\text { The demand for } \\
\text { natural gas } \\
{\left[\text { million } \mathrm{m}^{3} / \text { year }\right]}\end{array}$ & $\begin{array}{c}\text { Total energy demand } \\
{[\mathrm{GJ} / \mathrm{year}]}\end{array}$ & $\begin{array}{c}\text { Total amount } \\
\text { of waste heat } \\
{[\mathrm{GJ} / \text { year }]}\end{array}$ & $\begin{array}{c}\text { The amount } \\
\text { of waste heat } \\
\text { recovered } \\
{[\mathrm{GJ} / \text { year] }}\end{array}$ \\
\hline 20000 & 20.1 & 554400 & 415800 & 20790 \\
\hline
\end{tabular}

Heat recovery requires the use of air/liquid medium heat exchangers. Taking into account heat losses in the exchanger and during the flow of refrigerant from the exchanger to the cooler, it was assumed that only $70 \%$ of the recovered heat will be supplied to the adsorption chiller (Tab. 2).

TABLE 2. The estimation of the amount of heat transferred to adsorption cooler

TABELA 2. Oszacowanie ilości ciepła dostarczonego do chłodziarki adsorpcyjnej

\begin{tabular}{|c|c|c|}
\hline $\begin{array}{c}\text { The amount of waste heat recovered } \\
{[\mathrm{GJ} / \text { year] }}\end{array}$ & $\begin{array}{c}\text { The efficiency of the heat exchange } \\
\text { process }\end{array}$ & $\begin{array}{c}\text { The amount of heat transferred } \\
\text { to the adsorption cooler } \\
{[\mathrm{GJ} / \text { year] }}\end{array}$ \\
\hline 20790 & $70 \%$ & 14553 \\
\hline
\end{tabular}

The next step in the calculation was to assume that the coefficient of performance of the adsorber cooler is 0.5 . On this basis, the amount of cold that could be produced by this device was calculated. The results of the calculations are presented in Table 3.

In turn, the cooling power of the adsorption chiller was estimated. For this purpose, it was assumed that the glassworks operates 24 hours a day all year around, which results from the specificity of glass production. The results of the calculations are shown in Table 4. 
TABLE 3. Estimation of the amount of produced cold

TABELA 3. Oszacowanie ilości wyprodukowanego chłodu

\begin{tabular}{|c|c|c|c|}
\hline $\begin{array}{c}\text { The amount of heat } \\
\text { transferred } \\
\text { to the adsorption cooler } \\
\text { [GJ/year] }\end{array}$ & $\begin{array}{c}\text { The coefficient } \\
\text { of performance (COP) }\end{array}$ & $\begin{array}{c}\text { The amount of cold } \\
\text { produced } \\
\text { [GJ/year] }\end{array}$ & $\begin{array}{c}\text { The amount of cold } \\
\text { produced } \\
\text { [MWh] }\end{array}$ \\
\hline 14553 & 0.5 & 7277 & 2021 \\
\hline
\end{tabular}

TABLE 4. Estimation of the cooling power of the adsorption refrigerator

TABELA 4. Oszacowanie mocy chłodniczej chłodziarki adsorpcyjnej

\begin{tabular}{|c|c|c|}
\hline $\begin{array}{c}\text { The amount of cold produced } \\
{[\mathrm{MWh}]}\end{array}$ & $\begin{array}{c}\text { The number of plant operating hours } \\
\text { per year }[\mathrm{h}]\end{array}$ & Cooling power $[\mathrm{kW}]$ \\
\hline 2021 & 8760 & 231 \\
\hline
\end{tabular}

\subsection{The economic analysis of the proposed solution}

The economic analysis involved estimating the outlays for the construction of the refrigeration unit consisting of the heat recovery system and adsorption chiller and the savings resulting from the fact of cold production using waste heat. Using this data, the economic viability of the investment was assessed using the NPV criterion.

Taking the prices of SorTech and NET SA adsorption chillers (Technical... 2016) specified in the product catalogs of these companies into account, it can be concluded that the cost of purchasing an adsorption chiller with a cooling capacity of $231 \mathrm{~kW}$ is around PLN 900,000. Estimating the cost of building a heat recovery system powering the adsorption cooler is a very difficult task due to the innovative nature of such projects and the fact that such installation would have to be individually designed for a given glassworks. In connection with the above, an economic analysis of the proposed solution for different costs of a heat recovery system, which plays an important role in determining its economic viability, was presented.

The savings generated using an adsorption chiller result from the fact that it does not use electricity but is supplied with waste heat. The annual savings are therefore equal to the costs of generating $2021 \mathrm{MWh}$ of cold by a compressor chiller. For the purpose of further calculations, it was assumed that the coefficient of performance of the compressor chiller is 3.0. This allowed the amount of electricity saved per year to be calculated. In turn, it was assumed that the price of 1 MWh of electricity for an industrial plant is PLN 480. Using the above assumptions, the annual savings were determined (Tab. 5).

The assessment of the economic viability of the investment was carried out using the NPV method (Net Present Value), which is commonly used in such cases. The assumed discount rate was $5 \%$. It was assumed that the total cost of the investment will be financed by a bank loan with a fixed interest rate of $10 \%$ per annum. The loan term was 10 years. The next step was to calculate monthly 
TABLE 5. Estimation of the annual savings

TABELA 5. Oszacowanie rocznych oszczędności

\begin{tabular}{|c|c|c|c|c|}
\hline $\begin{array}{c}\text { The amount of cold } \\
\text { produced } \\
{[\mathrm{MWh}]}\end{array}$ & $\begin{array}{c}\text { The coefficient of } \\
\text { performance of } \\
\text { a compressor } \\
\text { chiller }\end{array}$ & $\begin{array}{c}\text { Electricity savings } \\
{[\mathrm{MWh}]}\end{array}$ & $\begin{array}{c}\text { The cost } \\
\text { of electricity } \\
{[\mathrm{PLN} / \mathrm{MWh}]}\end{array}$ & $\begin{array}{c}\text { Annual savings } \\
\text { [PLN] }\end{array}$ \\
\hline 2021 & 3.0 & 674 & 480 & 323520 \\
\hline
\end{tabular}
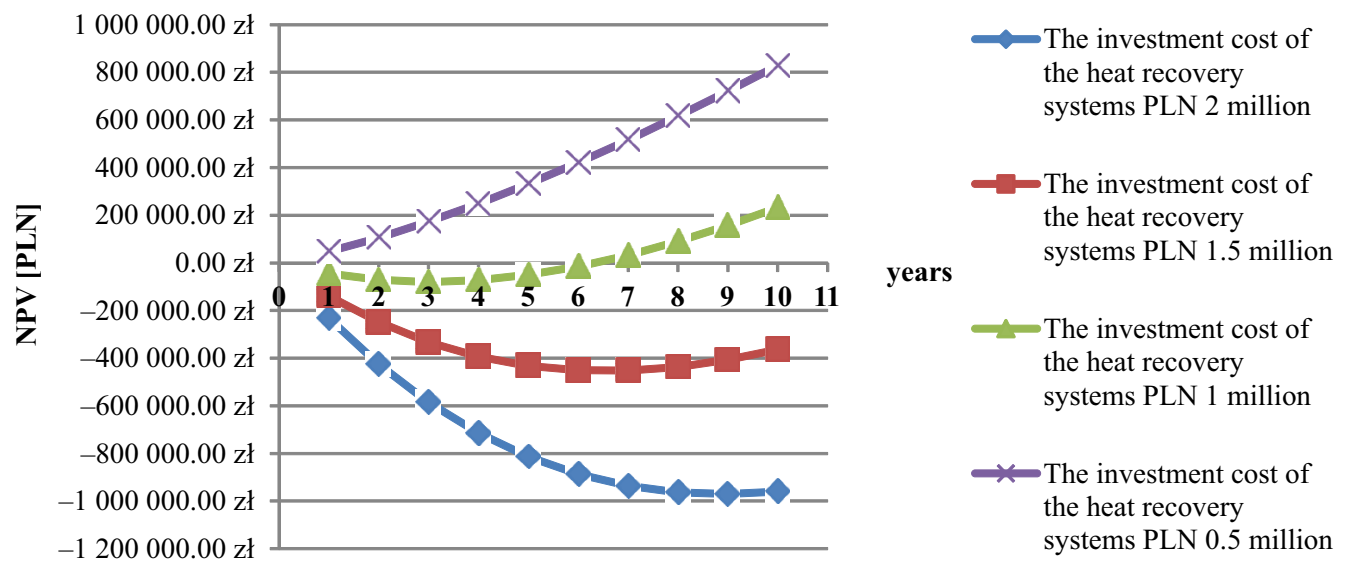

Fig. 4. NPV for four different costs of heat recovery system

Rys. 4. Wartości wskaźnika NPV dla czterech różnych kosztów budowy IOC

installments and interest rates, which allowed us to determine the annual costs of the loan repayment. Next, the NPV value, after 10 years from the implementation of the investment, was calculated. The calculations were carried out for four different construction costs of the heat recovery (IOC) system. The results of the calculations are shown in the graph (Fig. 4) and in table (Tab. 6).

TABLE 6 . The calculation of NPV

TABELA 6. Obliczenia NPV

\begin{tabular}{|c|c|c|c|c|c|}
\hline \multirow{2}{*}{$\begin{array}{l}\text { Expenses for the } \\
\text { construction of a heat } \\
\text { recovery system } \\
{[\text { PLN] }}\end{array}$} & \multicolumn{2}{|c|}{ Cash-in } & \multicolumn{2}{|c|}{ Cash-out } & \multirow{2}{*}{$\begin{array}{c}\text { NPV } \\
\text { after } 10 \text { years } \\
{[\text { PLN] }}\end{array}$} \\
\hline & $\begin{array}{l}\text { credit } \\
{[\mathrm{PLN}]}\end{array}$ & $\begin{array}{c}\text { savings } \\
{[\mathrm{PLN}]}\end{array}$ & $\begin{array}{l}\text { investment costs } \\
{[\text { PLN] }}\end{array}$ & $\begin{array}{c}\text { interest }+ \text { installments } \\
{[\text { PLN }]}\end{array}$ & \\
\hline $2,000,000$ & $2,900,000$ & 323,520 & $2,900,000$ & $4,362,083$ & $-959,926$ \\
\hline $1,500,000$ & $2,400,000$ & 323,520 & $2,400,000$ & $3,610,000$ & $-363,709$ \\
\hline $1,000,000$ & $1,900,000$ & 323,520 & $1,900,000$ & $2,857,917$ & 232,509 \\
\hline 500,000 & $1,400,000$ & 323,520 & $1,400,000$ & $2,105,833$ & 828,726 \\
\hline
\end{tabular}


The results of the economic analysis have shown that the investment in the adsorption cooler supplied with waste heat from the heat recovery system will bring significant economic benefits reaching almost PLN 233,000 after 10 years from the implementation assuming the investment cost is PLN 1,000,000.

\subsection{The analysis of benefits and problems related to the proposed solution}

The main advantage of an adsorption chiller powered by waste heat is the efficient use of heat which is usually irretrievably lost. In addition, the discussed solution leads to a reduction of the electricity consumption needed to power traditional compressor chillers used for air-conditioning of workplaces. The reduction of electricity consumption translates into financial savings for the company and ecological benefits. The proposed solution results in the reduction of $\mathrm{CO}_{2}$ emissions associated with electricity generation and thus is in line with the European Union's climate and energy policy, which may also be related to image benefits.

The use of an adsorption chiller powered by waste heat seems to be the right solution in the era of continuous increases of electricity prices and requirements regarding working conditions. High temperature zones in glassworks are related to the risk of occupational diseases and undoubtedly negatively affect the efficiency of the work. In light of the above, air conditioning of work stations should be used. The cooling demand in summer, associated with air-conditioning of office buildings, is also worth noting. Therefore, the refrigeration system in the discussed industrial plant is undoubtedly needed, and the choice of an adsorption chiller instead of compressor refrigerators may make the plant independent of electricity prices.

The proposed solution is associated with high investment costs related to the purchase of an adsorption chiller and the construction of a dedicated heat recovery system. It should also be borne in mind that the design of a heat recovery system may pose numerous technical problems and require expensive analysis, tests, and simulations. When designing such a system one should take a number of problems into account, including the need to make sure that the installation does not have a significant impact on the temperatures during the glass melting process due to the possibility of lowering its quality. In addition, the system must be mounted in a way enabling the recovery of as much waste heat as possible at the optimum temperature for the adsorption chiller. Finally, there is a need to take the impact of various chemical compounds on heat exchanger materials into account. It is also worth paying attention to the use of the cold produced by the adsorption chiller. When the cooling demand in the glassworks is lower than the capacity of the adsorption chiller it is not possible to effectively use all of the produced cold, which affects the payback period of the project. 


\section{Conclusions}

The adsorption chiller technology meets the current needs to reduce electricity consumption and increase the energy efficiency. The most important benefits associated with its application include the possibility of using low-temperature heat, which is usually irretrievably lost, and the possibility of making cold production independent of the electricity supplies.

Due to a low coefficient of performance COP and high investment expenditures, the adsorption chillers cannot be competitive at the moment in relation to their compressor and absorption counterparts. In light of the above, there is an urgent need for further studies aimed at increasing the efficiency of adsorption devices. The possible solutions include the use of new materials with appropriate properties or modifications of already used adsorbents and adsorbates.

The example presented in the paper was intended to draw attention to the fact that adsorption chillers can be supplied with waste heat from industrial production. As shown by economic analysis, the use of the mentioned refrigeration equipment in a glassworks can bring profits after only seven years from the investment, assuming that the demand for cooling will be equal to cold production and the investment costs will not exceed PLN 1 million.

\section{References}

Adsorption cooling systems. [Online] http://www.abschiller.ru/index.php/adsorbtsionnye-chillery [Accessed: 2018-11-03].

Adsorption machines - a combination of cooling and solar energy (Adsorpcyonnyje maszyny - soczetanije ochłażdienija i eniergii solnca). [Online] https://caxapa.ua/ru/kompaniya/statti/ [Accessed: 03.11.2018] (in Ukrainian).

Air conditioning of large buildings (Kondicyonirowanije wozducha na krupnych objektach). [Online] https://planetaklimata.com.ua/articles/?msg=989 [Accessed: 2018-11-03].

AL-Mousawi et al. 2016 - AL-MousaWI, F.N., AL-DADAH, R. and MAHMOUd, S. 2016. Novel adsorption system for cooling and power generation utilizing low grade heat sources. International Conference on Applied Engineering Vol. 12, Issue 2, pp. 215-227.

AMBARITA, H. and KAWAI, H. 2016. Experimental study on solar-powered adsorption refrigeration cycle with activated alumina and activated carbon as adsorbent. Case Studies in Thermal Engineering Vol. 7, pp. 36-46.

Technical and economical analysis of cold production using district heating network (Analiza techniczno-ekonomiczna produkcji chłodu z wykorzystaniem miejskiej sieci ciepłowniczej). [Online] http://kne.itc. pw.edu.pl/attachments/article/169/ [Accessed: 2018-11-12] (in Polish).

Bagdujew, G. and Czalajew, D. 2008. Solar shower. Bulletin of the Dagestan State Pedagogical University (Colniecznoe oxłażgenie. Izwiestija Dagiestanskogo gosudarstwiennogo piedagogiczeskogo uniwiersitieta). Естественные и точныенауки (Exact sciences and natural sciences) Vol. 2, pp. 2-8. 
Bakker et al. 2013 - Bakker, E., De Boer, R., Smeding, S., Sijpheer, R. and VAn Der Pal, M. 2013. Development of an innovative 2,5 kW Water-Silica Gel Adsorption Chiller. Report of Energy Research Centre of the Netherlands Vol. 8, pp. 15-25.

Boelman et al. 1995 - Boelman, E.C., SAHA, B.B. And KASHIWAGi, T., 1995. Experimental investigation of a silica gel-water adsorption refrigeration cycle - the influence of operating conditions on cooling output and COP. ASHRAE Transactions Vol. 101, pp. 358-366.

Communication from the Commission to The European Parliament, The Council, The European Economic and Social Committee and The Committee of The Regions. A policy framework for climate and energy in the period from 2020 to $2030, \mathrm{COM} / 2014 / 015$.

FAN et al. 2007 - FAN, Y., LUO, L. and SOUYRI, B. 2007. Review of solar sorption refrigeration technologies: Development and applications. Renewable and Sustainable Energy Reviews Vol. 11, pp. 1758-1775.

GRZEBIELEC, A. 2005. Application and prospects of development of adsorption refrigeration equipment in refrigeration and air conditioning (Zastosowanie i perspektywy rozwoju adsorpcyjnych urzadzeń chłodniczych $w$ chłodnictwie i klimatyzacji). Chłodnictwo i Klimatyzacja Vol. 4, pp. 52-57 (in Polish).

GRZEBIELEC et al. 2015 - GrZEBIELEC, A., RuSOwiCZ, A., JAWORSKI, M. and ŁASKOWSKI, R. 2015. Possibility of using adsorption refrigeration unit in district heating network. Archives of thermodynamics Vol. 36, Issue 3, pp. 15-24.

GWADERA, M. and KUPIEC, K. 2011. Adsorptionrefrigerationsystems (Adsorpcyjne układy chłodnicze). Inżynieria i aparatura chemiczna Vol. 50, Issue 5, pp. 38-39.

HAMmOND, G. and NoRman, J. 2014. Heat recovery opportunities in UK industry. Applied Energy Vol. 116, pp. 387-397.

HAMRAHI et al. 2018 - HAMRAHI, S.E., GOUDARZI, K. and YAGHOUBI, M. 2018. Experimental study of the performance of a continues solar adsorbtion chiller using nano-activated carbon/metanol as working pair. Solar Energy Vol. 173, pp. 920-927.

JiANGZHOU et al. 2003 - JiANGZHOU, S., WANG, R.Z., LU, Y.Z., XU, Y.X., WU, J.Y. and Li Z.H. 2003. Locomotive driver cabin adsorption air-conditioner. Renewable Energy Vol. 28, pp. 1659-1670.

KUCHMACZ, J. and MiKA, Ł. 2018. Possibilities of use and management of low-temperature waste heat from industrial processes (Możliwości wykorzystania i zagospodarowania niskotemperaturowego ciepła odpadowego z procesów przemystowych). Poszerzamy horyzonty Vol. 7, pp. 234-248 (in Polish).

KUCZYŃSKA, A. and SZAFLIK, W. 2010. Absorption and adsorption chillers applied to air conditioning systems. Archives of Thermodynamics Vol. 31, pp. 77-94.

LIU et al. 2005 - LIU, Y.L., WANG, R.Z. and XIA, Z.Z. 2005. Experimental performance of a silica gel water adsorption chiller. Applied Thermal Engineering Vol. 25, pp. 359-375.

LI et al. 2016 - LI, W., Joshi, Ch., XU, P. and SCHMIDT, F. 2016. Experimental study on adsorption refrigeration system with stratified storage - Analysis of storage discharge operations. Procedia Engineering Vol. 146, pp. 625-631.

Najeh et al. 2016 - Najeh, G., Silmane, G., Souad, M., Riad, B. and Mohammed, G. 2016. Performance of silica gel-water solar adsorbtion cooling system. Case Studies in Thermal Engineering Vol. 8, pp. 337-345.

Pralon, A. and Daguenet, M. 2000. Performance of a new solid adsorption ice maker with solar energy regeneration. Energy Conversion and Management Vol. 41, pp. 1625-1647.

Restuccia et al. 2004 - Restuccia, G., Freni, A., VAsta, S. and ARISTOV, Y. 2004. Selective water sorbent for solid sorption chiller: experimental results and modeling. International Journal of Refrigeration pp. 284-293.

RUDENKO, M.F., 2008. Development and research of the efficiency of the adsorption solar cooling plant (Razrabotka $i$ issledowanije effiektiwnosti adsorbcyonnoj gieliochołodilnoj ustanowki). Wiestnik 
mieżdunarodnoj akadiemii chołoda (Bulletin of the International Academy of Refrigeration) Vol. 2, pp. 34-37 (in Russian).

RudENKO, M.F. and SzYPULINA, J. 2011. Simulation of the thermodynamic cycle of the adsorption solar thermal transformer (Modielirowanije tiermodinamiczeskogo cykla raboty adsorbcyonnogo gielioeniergieticzeskogo tiermotransformator). Wiestnik Astrachanskogo Gosudarstwiennogo Tiechniczeskogo Uniwiersitieta (Bulletin of the Astrakhan State Technical University). Sierija: Morskaja tiechnika i tiechnołogi Vol. 3, pp. 136-140 (in Russian).

SONG et al. 2015 - SonG, X., Ji, X., LI, M., WANG, Q., DAI, Y. and LiU, J. 2015. Effect of desorption parameters on performance of solar water-bath solid adsorption ice-making system. Applied Thermal Engineering Vol. 89, pp. 316-322.

WANG et al. 2004 - WANG, L.W., WANG, R.Z., WU, J.Y., WANG, K. and WANG, S.G. 2004. Adsorption ice makers for fishing boats driven by the exhaust heat from diesel engine: choice of adsorption pair. Energy Conversion and Management Vol. 45, pp. 2043-2057.

WeISSER, P. and SKOTNICKI, P. 2016. Perspective of application the ORC systems at low temperature waste energy (Perspektywy wykorzystania układów ORC przy niskotemperaturowej energii odpadowej). Prace Instytutu Ceramiki i Materiałów Budowlanych Vol. 6, pp. 114-122 (in Polish).

Thermalwaters (Wody termalne). [Online] https://mineralne.pgi.gov.pl/wody-termalne.html [Accessed: 2018-11-02] (in Polish).

\title{
Wykorzystanie chłodziarek adsorpcyjnych do zagospodarowania ciepła odpadowego
}

\author{
Streszczenie
}

Celem artykułu było rozważenie problemu zagospodarowywania ciepła odpadowego przy wykorzystaniu chłodziarek adsorpcyjnych. Na początku wskazano genezę potrzeby podjęcia szerszych działań na rzecz efektywnego zagospodarowywania ciepła odpadowego w przemyśle oraz omówiono korzyści i problemy techniczne związane z odzyskiem ciepła w zakładach przemysłowych. W następnym rozdziale objaśniono zasadę działania chłodziarek adsorpcyjnych. Z kolei wskazano źródła ciepła dla chłodziarek adsorpcyjnych oraz opisano ich przykładowe zastosowania. Powyższe rozważania pozwoliły na uwypuklenie korzyści i barier technicznych związanych z wykorzystywaniem adsorpcyjnych urządzeń chłodniczych. W następnej części pracy scharakteryzowano stosowane obecnie adsorbenty i adsorbaty. W zasadniczej części pracy przeprowadzono analizę wykorzystania chłodziarek adsorpcyjnych do zagospodarowania ciepła odpadowego w hucie szkła. W obliczeniach rozważono przykładową hutę szkła, której zapotrzebowanie na gaz ziemny wynosi $20,1 \mathrm{mln} \mathrm{m}^{3} / \mathrm{rok}$, a zapotrzebowanie na energię elektryczną wynosi $20000 \mathrm{MWh} / \mathrm{rok}$. W efekcie przeprowadzonych kalkulacji dobrano chłodziarkę adsorpcyjną o mocy $231 \mathrm{~kW}$, która zapewni roczną produkcję chłodu wynoszącą $2021 \mathrm{MWh}$. Analiza ekonomiczna zaproponowanego rozwiązania wykazała, że inwestycja w chłodziarkę adsorpcyjną zasilaną ciepłem odpadowym z instalacji odzysku ciepła 
przyniesie znaczące korzyści ekonomiczne po 10 latach od jej zrealizowania nawet przy sumarycznych nakładach inwestycyjnych wynoszących 1900000 zł. Zaznaczono jednak, że uzyskanie tak zadawalających wyników ekonomicznych będzie możliwe tylko wtedy, gdy w hucie szkła będzie zapewniony ciągły odbiór chłodu, a koszt budowy instalacji odzysku ciepła nie przekroczy $1 \mathrm{mln}$ zł.

SŁOWA KLUCZOWE: ciepło odpadowe, odzysk ciepła, efektywność energetyczna, chłodziarki adsorpcyjne 